\title{
LITERATURE REVIEW ON MAXIMUM LOADING OF RADIONUCLIDES ON CRYSTALLINE SILICOTITANATE
}

OCTOBER 2010

Savannah River National Laboratory Savannah River Nuclear Solutions Aiken, SC 29808

Prepared for the U.S. Department of Energy Under Contract Number DE-AC09-08SR22470

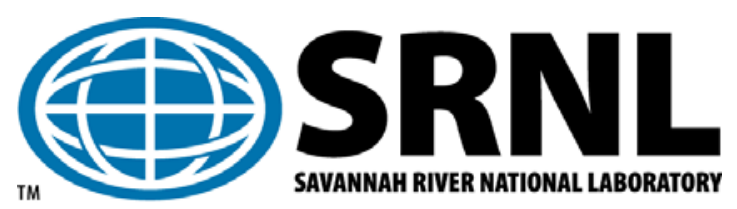




\section{DISCLAIMER}

This work was prepared under an agreement with and funded by the U.S. Government. Neither the U. S. Government or its employees, nor any of its contractors, subcontractors or their employees, makes any express or implied:

1. Warranty or assumes any legal liability for the accuracy, completeness, or for the use or results of such use of any information, product, or process disclosed; or

2. Representation that such use or results of such use would not infringe privately owned rights; or

3. Endorsement or recommendation of any specifically identified commercial product, process, or service.

Any views and opinions of authors expressed in this work do not necessarily state or reflect those of the United States Government, or its contractors, or subcontractors.

This document was prepared in conjunction with work accomplished under Contract No. DE-AC09-08SR22470 with the U.S. Department of Energy.

\section{Printed in the United States of America}

Prepared For

U.S. Department of Energy 
Key Words:

Maximum loading

Crystalline Silicotitanate (CST)

Sorption capacity

Sorption distribution coefficient

Small-column ion exchange (SCIX)

\title{
Retention: Permanent
}

\section{Key References:}

Task Plan for Thermal Modeling of CST Columns and CST Maximum Loading Determinations, SRNL-TR-2010-00081, Rev. 0, March, 2010.

\section{LITERATURE REVIEW ON MAXIMUM LOADING OF RADIONUCLIDES ON CRYSTALLINE SILICOTITANATE}

\author{
K. Adu-Wusu, SRNL/E\&CPT \\ F. M. Pennebaker, SRNL/E\&CPT
}

Issue Date: October 2010

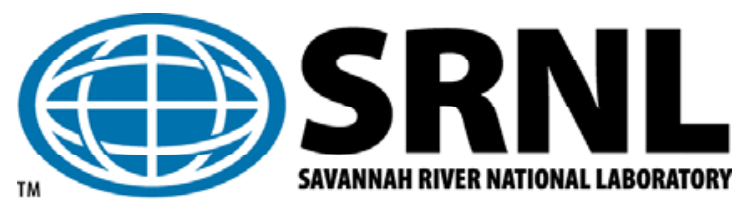




\section{REVIEWS AND APPROVALS}

\section{Author:}

K. Adu-Wusu, Author, SRNL/E\&CPT Research Programs

Date

\section{Reviewer:}

W. D. King, Technical Reviewer, SRNL/E\&CPT Research Programs

Date

\section{SRNL Management:}

F. M. Pennebaker, Manager SRNL/E\&CPT Research Programs

Date

S. L. Marra, Manager SRNL/E\&CPT Research Programs

Date

Savannah River Remediation:

T. H. Huff, Deputy Manager, SCIX Project Engineering Date 


\section{TABLE OF CONTENTS}

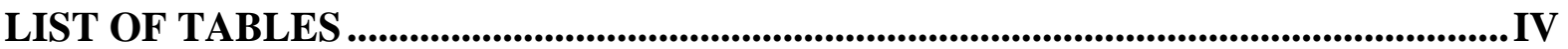

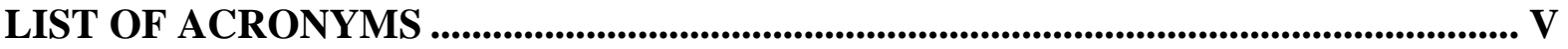

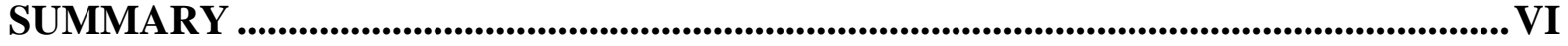

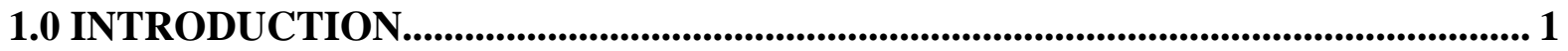

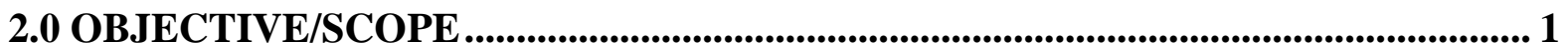

3.0 MAXIMUM RADIONUCLIDE LOADING ESTIMATES ..................................... 2

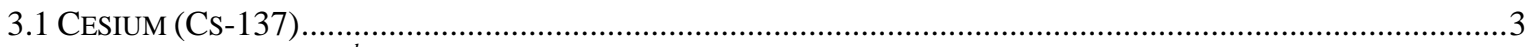

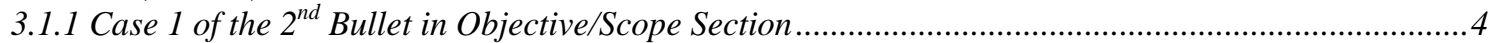

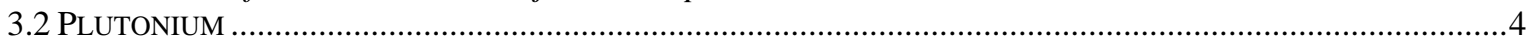

3.3 BARIUM (BA-137M)...........................................................................................................

3.3.1 Ba-137m Activity from the Supernate .................................................................................5

3.3.2 Activity from the Decay of the Cs-137 Loaded on the CST to Ba-137m .......................................6

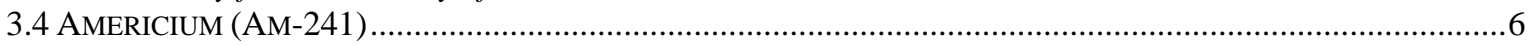

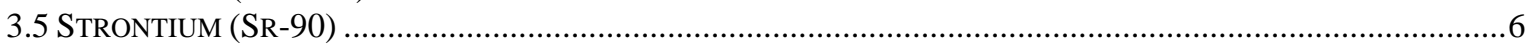

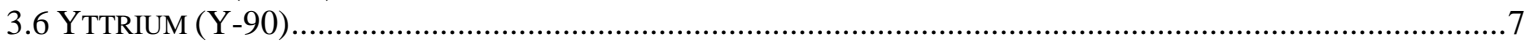

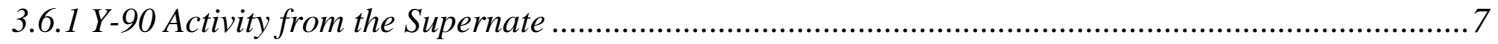

3.6.2 Activity from the Decay of the Sr-90 Loaded on the CST to Y-90 .................................................

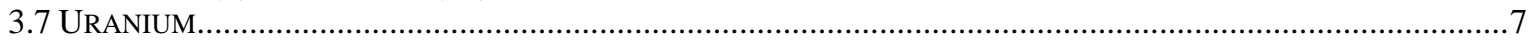

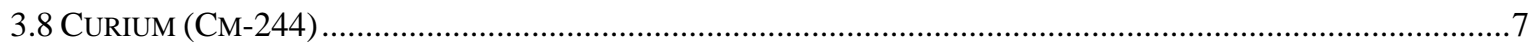

3.9 CASE 2 OF THE $2^{\text {ND }}$ BULLET IN OBJECTIVE/SCOPE SECTION .............................................................. 7

4.0 CONCLUSION

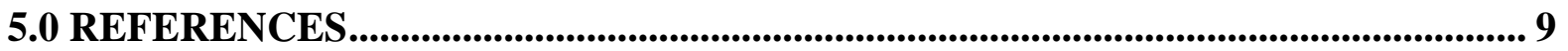




\section{LIST OF TABLES}

TABle 1. MAXIMUM AND Nominal RADIONUClide CONCENTRATIONS IN WASTE TANK

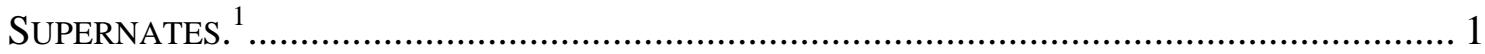

TABle 2. CS LOADING ON CST for VARIOUS ISOTOPIC PROPORTIONS IN THE WASTE........... 3

TABLE 3. SUMMARY OF THE ESTIMATES OF RADIONUCLIDE LOADINGS ON CST. .................. 8 


\section{LIST OF ACRONYMS}

$\begin{array}{ll}\text { BV } & \text { Bed volume } \\ \mathrm{C}_{f} & \text { Final cesium concentration } \\ \mathrm{C}_{\mathrm{i}} & \text { Initial cesium concentration } \\ \mathrm{CST} & \text { Crystalline silicotitanate } \\ \text { E\&CPT } & \text { Environmental \& Chemical Process Technology } \\ \mathrm{K}_{\mathrm{d}} & \text { Sorption distribution coefficient } \\ \mathrm{m} & \text { Mass of sorbent } \\ \text { MST } & \text { Monosodium Titanate } \\ \text { RCRA } & \text { Resource Conservation and Recovery Act } \\ \mathrm{S} & \text { Sorption capacity } \\ \text { SCIX } & \text { Small column ion exchange } \\ \text { SRNL } & \text { Savannah River National Laboratory } \\ \text { SRR } & \text { Savannah River Remediation } \\ \text { SRS } & \text { Savannah River Site } \\ \text { V } & \text { Volume of solution }\end{array}$




\section{SUMMARY}

Plans are underway to use small column ion exchange (SCIX) units installed in high-level waste tanks to remove Cs-137 from highly alkaline salt solutions at Savannah River Site. The ion exchange material slated for the SCIX project is engineered or granular crystalline silicotitanate (CST). Information on the maximum loading of radionuclides on CST is needed by Savannah River Remediation for safety evaluations.

A literature review has been conducted that culminated in the estimation of the maximum loading of all but one of the radionuclides of interest (Cs-137, Sr-90, Ba-137m, Pu-238, Pu239, Pu-240, Pu-241, Am-241, and Cm-244). No data was found for Cm-244. 


\subsection{INTRODUCTION}

This report deals with a literature search for data relevant to the estimation of the maximum radionuclide loading on crystalline silicotitanate (CST) for Savannah River Remediation (SRR). CST is the sorbent for the Small Column Ion Exchange (SCIX) project. Data on maximum loading of radionuclides on CST will be used by SRR for safety assessments.

The specifics of the objective and scope of work are outlined below. ${ }^{2}$

\subsection{OBJECTIVE/SCOPE}

- Perform literature review to find data to help estimate the maximum radionuclide loading that can be attained on CST sorbent.

- Key radionuclides of interest include Cs-137, Sr-90, Ba-137m, Pu-238, Pu-239, $\mathrm{Pu}-240, \mathrm{Pu}-241, \mathrm{Am}-241$ and $\mathrm{Cm}-244$.

- Bounding and nominal liquid phase radionuclide concentrations will be those provided in the Engineering Document, S-CLC-G-00235, Rev. 3. ${ }^{1}$ Table 1 gives the bounding and nominal radionuclide concentrations.

- Investigate two cases of loading.

- Case 1: A fully loaded column defined as the point where the lag column bucket average effluent reaches $45 \mathrm{nCi} / \mathrm{g}$.

- Case 2: Maximum loading for spent CST sorbent discharged to a waste tank for a prolonged period of time.

Table 1. Maximum and Nominal Radionuclide Concentrations in Waste Tank Supernates. ${ }^{1}$

\begin{tabular}{|l|c|c|c|c|}
\hline Isotope & \multicolumn{2}{|c|}{ Maximum Concentration } & \multicolumn{2}{c|}{ Nominal Concentration } \\
\hline Units & $\mathrm{Ci} /$ gal & $\mu \mathrm{Ci} / \mathrm{mL}$ & $\mathrm{Ci} / g a l$ & $\mu \mathrm{Ci} / \mathrm{mL}$ \\
\hline $\mathrm{Sr}-90$ & $0.00 \mathrm{E}+00$ & $0.00 \mathrm{E}+00$ & $0.00 \mathrm{E}+00$ & $0.00 \mathrm{E}+00$ \\
\hline $\mathrm{Y}-90$ & $0.00 \mathrm{E}+00$ & $0.00 \mathrm{E}+00$ & $0.00 \mathrm{E}+00$ & $0.00 \mathrm{E}+00$ \\
\hline $\mathrm{Cs}-137$ & $4.20 \mathrm{E}+01$ & $1.11 \mathrm{E}+04$ & $9.80 \mathrm{E}+00$ & $2.59 \mathrm{E}+03$ \\
\hline $\mathrm{Ba}-137 \mathrm{~m}$ & $4.00 \mathrm{E}+01$ & $1.06 \mathrm{E}+04$ & $9.20 \mathrm{E}+00$ & $2.43 \mathrm{E}+03$ \\
\hline $\mathrm{Pu}-238$ & $1.40 \mathrm{E}-02$ & $3.70 \mathrm{E}+00$ & $5.70 \mathrm{E}-03$ & $1.51 \mathrm{E}+00$ \\
\hline $\mathrm{Pu}-239$ & $1.70 \mathrm{E}-03$ & $4.49 \mathrm{E}-01$ & $4.80 \mathrm{E}-04$ & $1.27 \mathrm{E}-01$ \\
\hline $\mathrm{Pu}-240$ & $3.80 \mathrm{E}-04$ & $1.00 \mathrm{E}-01$ & $1.20 \mathrm{E}-04$ & $3.17 \mathrm{E}-02$ \\
\hline $\mathrm{Pu}-241$ & $1.00 \mathrm{E}-02$ & $2.64 \mathrm{E}+00$ & $3.40 \mathrm{E}-03$ & $8.98 \mathrm{E}-01$ \\
\hline $\mathrm{Am}-241$ & $1.30 \mathrm{E}-02$ & $3.43 \mathrm{E}+00$ & $1.20 \mathrm{E}-03$ & $3.17 \mathrm{E}-01$ \\
\hline $\mathrm{Cm}-244$ & $4.00 \mathrm{E}-03$ & $1.06 \mathrm{E}+00$ & $1.10 \mathrm{E}-04$ & $2.91 \mathrm{E}-02$ \\
\hline
\end{tabular}


SRNL-TR-2010-00277, REV. 0

\subsection{MAXIMUM RADIONUCLIDE LOADING ESTIMATES}

An extensive literature search was conducted by combing through over 600 pages of search hits comprising over 560 abstracts/citations. It was followed by a review of the relevant detailed reports and papers. The information needed for each radionuclide include

- Spent CST analysis after column tests.

- Breakthrough curves from column tests or models and associated feed concentrations, column effluent concentrations, and volumes of feed processed.

- Sorption equilibrium isotherms from either batch contact tests, column tests or modeling.

- Sorption distribution coefficients (from batch contact tests) and final concentrations or sorption distribution coefficients and sorption capacities or sorption distribution coefficients along with initial concentrations and phase ratios. The equations below allow calculation of the unknowns to make the data complete.

The loading or sorption capacity (S) is given by

$$
\begin{aligned}
& S=K_{d} C_{f} \\
& S=\left(C_{i}-C_{f}\right) V / m
\end{aligned}
$$

where $K_{d}$ is the sorption distribution coefficient, $C_{i}$ is the initial concentration, $C_{f}$ is the final concentration, $\mathrm{V}$ is the volume of solution, $\mathrm{m}$ is the dry mass of CST, and $\mathrm{V} / \mathrm{m}$ is the phase ratio.

All the above loading information depends on the composition of the waste solution especially the desired radionuclide. However, other constituents (i.e., background constituents) in the solution may affect the loading data. Ideally, the wish was to have several background constituent concentrations of the needed information available for a range of each radionuclide concentration. Such information would have enabled the selection of the worst-case scenario maximum loading for the particular radionuclide.

The general findings from the literature search are as follows.

- There is no data at the high concentration levels stipulated in the Engineering Document ${ }^{1}$ (Table 1) for any of the radionuclides except Cs and Sr isotherm modeling data.

- Limited number of references for data other than Cs.

The sections below discuss the estimates for the various radionuclides. For conservatism, all the estimates are based on powdered CST data. In other words, no "dilution factor" was applied for the engineered or granular CST. 


\subsection{Cesium (Cs-137)}

Cesium loading is largely unaffected by varying the concentration of various feed solution components (Cs, $\mathrm{Na}, \mathrm{K}$ and $\mathrm{OH}$ ) and temperature as long as the concentration of cesium is above $4 \mathrm{mM}^{3,4}$ This is because the Cs sorption or loading isotherm for CST reaches its maximum capacity $(0.58 \mathrm{mmole} / \mathrm{g})$ at Cs concentrations of $4.00 \mathrm{E}-03 \mathrm{M}$ and beyond. The ions mentioned above generally have the greatest impact on Cs loading. Differences in Cs loading for varying conditions increase as the Cs concentration decreases from 4.00E-03 to 5.00E-04 M. However, they become appreciable only towards or near 5.00E-04 M. The difference is predicted to be about $15 \%$ at $5.00 \mathrm{E}-04 \mathrm{M}$ Cs concentration based on a value of $28 \%$ at $2.28 \mathrm{E}-05 \mathrm{M}$ Cs concentration. $^{4}$

Table 2 gives the estimated loading data for Cs for both the maximum and nominal Cs concentration cases based on ZAM isotherm model predictions. Depending on the percent Cs137 in the total $\mathrm{Cs}$, the estimated loading ranges from $1.34 \mathrm{E}+00$ and $2.52 \mathrm{E}+00 \mathrm{Ci} / \mathrm{g}$ for the maximum case; and $1.26 \mathrm{E}+00$ and $1.92 \mathrm{E}+00 \mathrm{Ci} / \mathrm{g}$ for the nominal case with $2.52 \mathrm{E}+00$ being the uppermost or bounding value. Note that the 5.00E-05 M Cs concentration was used in the previous paragraph because the lowest Cs concentration in Table 2 is 5.43E-04 M (at 40\% Cs137). Also, the feed Na concentration for the model predictions ranged from 6 to $8 \mathrm{M}$.

The maximum case loading value for $25 \%$ Cs-137 agrees well with one of the values (1.63 Ci/g) selected for thermal modeling calculations.

Table 2. Cs Loading on CST for Various Isotopic Proportions in the Waste.

\begin{tabular}{|c|c|c|c|c|c|c|}
\hline \multicolumn{7}{|c|}{ Maximum Cs Supernate Concentration } \\
\hline & & & $40 \%$ Cs-137 & $30 \%$ Cs-137 & 25\% Cs-137 & $20 \%$ Cs-137 \\
\hline Units & Ci Cs-137/gal & $\mu \mathrm{Ci}$ Cs-137/mL & $\begin{array}{l}\text { moles total } \\
\text { Cs/L }\end{array}$ & $\begin{array}{l}\text { moles total } \\
\text { Cs/L }\end{array}$ & $\begin{array}{l}\text { moles total } \\
\text { Cs/L }\end{array}$ & $\begin{array}{l}\text { moles total } \\
\text { Cs/L }\end{array}$ \\
\hline $\begin{array}{l}\text { Cs } \\
\text { Concentration }\end{array}$ & $4.20 \mathrm{E}+01$ & $1.11 \mathrm{E}+04$ & 2.33E-03 & $3.10 \mathrm{E}-03$ & 3.72E-03 & 4.65E-03 \\
\hline $\begin{array}{l}\text { Cs Loading on } \\
\text { CST, Ci/g }\end{array}$ & $\mathrm{n} / \mathrm{a}$ & $\mathrm{n} / \mathrm{a}$ & $2.52 \mathrm{E}+00$ & $1.97 \mathrm{E}+00$ & $1.68 \mathrm{E}+00$ & $1.34 \mathrm{E}+00$ \\
\hline \multicolumn{7}{|c|}{ Nominal Cs Supernate Concentration } \\
\hline & & & $40 \%$ Cs-137 & $30 \%$ Cs-137 & $25 \%$ Cs-137 & $20 \%$ Cs-137 \\
\hline Units & Ci Cs-137/gal & $\mu \mathrm{Ci}$ Cs-137/mL & $\begin{array}{c}\text { moles total } \\
\mathrm{Cs} / \mathrm{L}\end{array}$ & $\begin{array}{c}\text { moles total } \\
\mathrm{Cs} / \mathrm{L}\end{array}$ & $\begin{array}{c}\text { moles total } \\
\mathrm{Cs} / \mathrm{L}\end{array}$ & $\begin{array}{c}\text { moles total } \\
\mathrm{Cs} / \mathrm{L}\end{array}$ \\
\hline $\begin{array}{l}\text { Cs } \\
\text { Concentration }\end{array}$ & $9.80 \mathrm{E}+00$ & $2.59 \mathrm{E}+03$ & 5.43E-04 & 7.24E-04 & 8.69E-04 & 1.09E-03 \\
\hline $\begin{array}{l}\text { Cs Loading on } \\
\text { CST, Ci/g }\end{array}$ & $\mathrm{n} / \mathrm{a}$ & $\mathrm{n} / \mathrm{a}$ & $1.92 \mathrm{E}+00$ & $1.53 \mathrm{E}+00$ & $1.42 \mathrm{E}+00$ & $1.26 \mathrm{E}+00$ \\
\hline
\end{tabular}

n/a - not applicable 


\subsubsection{Case 1 of the $2^{\text {nd }}$ Bullet in Objective/Scope Section}

The loading information can only be obtained from dual-column (i.e., lead and lag) tests with carefully designed effluent fraction collection times and possibly, for Cs and Sr, from dualcolumn modeling runs.

Frank Smith ${ }^{5}$ performed dual-column CST modeling runs for Cs on several Savannah River Site (SRS) dissolved saltcakes (Tanks 1-3, 37 and 41) in 2007. In all cases, the lead column was almost fully loaded when the lag column bucket average effluent Cs-137 concentration reached $45 \mathrm{nCi} / \mathrm{g}$. Even though, the total Cs concentrations in the above waste tanks are relatively low compared to those stipulated in Table 1, it can be assumed that fully loaded lead columns will prevail at the maximum and nominal Cs concentrations in Table $1{ }^{4}$ Hence, the Cs loading values for a lead column with a lag column bucket average effluent Cs-137 concentration of $45 \mathrm{nCi} / \mathrm{g}$ will be the same as the values in Table 2. Note that the above is strictly based on lag column bucket average effluent Cs-137 concentration of $45 \mathrm{nCi} / \mathrm{g}$. The $45 \mathrm{nCi} / \mathrm{g}$ value given in the Objective/Scope section refers to lag column bucket average effluent total activity concentration.

Dual-columns will be run until the lag column effluent reaches $45 \mathrm{nCi} / \mathrm{g}$ for Cs-137. Hence, the lead column loadings of the other radionuclides cannot be higher than the values given in Table 3.

\subsection{Plutonium}

The only relevant work on Pu loading on CST that has been uncovered is the work by Wilmarth et al. in $2004 .^{6}$ The work used Tank $41 \mathrm{H}$ dissolved salt cake simulant containing no Cs and no Resource Conservation and Recovery Act (RCRA) metals that are typically in Tank $41 \mathrm{H}^{7}$ Plutonium (94 wt\% Pu-239 and $6 \mathrm{wt} \% \mathrm{Pu}-240$ ) and U (enriched) were added to the simulant at concentrations near saturation levels. The initial concentrations of $\mathrm{Pu}$ and $\mathrm{U}$ were not given; however, values were near saturation levels.

Three thousand bed volumes (BV) of the feed simulant solution were passed through the CST column. It was followed by washing of the CST bed with $200 \mathrm{BV}$ of inhibited water before analyzing the spent CST for Pu and U. The results of the spent CST analysis were as follows.

$$
\begin{aligned}
& \mathrm{Pu}-239=4,062 \mathrm{nCi} / \mathrm{g}=4.06 \mathrm{E}-06 \mathrm{Ci} / \mathrm{g}=64.5 \mu \mathrm{g} / \mathrm{g} \\
& \mathrm{U}=360 \mu \mathrm{g} / \mathrm{g}
\end{aligned}
$$

Since only Pu-239 was measured, total Pu activity in the CST can be calculated to be 5,015 $\mathrm{nCi} / \mathrm{g}(5.02 \mathrm{E}-06 \mathrm{Ci} / \mathrm{g}=68.6 \mu \mathrm{g} / \mathrm{g})$ using $\mathrm{Pu}-239 / \mathrm{Pu}-240$ activity ratio of 81 to $19 .^{7,8}$

The major characteristics of Wilmarth et al.'s work which suggest the above loading values are on the bounding or high side are:

(i) 3,000 BV of simulant solution was passed through the column. The maximum $\mathrm{BV}$ anticipated in the actual SCIX process will generally be less than $1,000 .^{3,4,9}$ 
(ii) Cs was not added to the feed simulant. Since CST has the greatest affinity for Cs, the absence of Cs makes mores sites on the CST available for the $\mathrm{Pu}$ and $\mathrm{U}$ sorption or uptake.

(iii) RCRA metals were not added. Even though RCRA metals are sorbed to only a limited extent compared to Cs, their absence reduces competition for the sorption sites on the CST.

In addition, monosodium Titanate (MST) strike will lower the Pu concentration prior to CST sorption.

Other items to consider based on experimental design:

(a) Since $\mathrm{Pu}$ and $\mathrm{U}$ were added at or near saturation levels in the test, it is quite possible the uptake or loading of $\mathrm{Pu}$ and $\mathrm{U}$ may have been due in part to precipitation. However, the expectation is that the feed to the SCIX unit will most likely be below saturation with respect to $\mathrm{Pu}$ and $\mathrm{U}$. The loading value may be lower without precipitation.

(b) Specific activity of Pu-238 is two orders of magnitude greater than that of Pu239. SRS has many waste tanks, including Tank $41 \mathrm{H}$, which have generally higher activities of Pu-238. ${ }^{1,7}$ CST will load the same mass of plutonium under similar conditions; thus, the activities will be higher for waste streams with relatively high $\mathrm{Pu}-238$.

\subsection{Barium (Ba-137m)}

\subsubsection{Ba-137m Activity from the Supernate}

Even though the half-life of Ba-137m is 2.55 minutes, it will contribute to the activity because Ba-137m in the solution or supernate will be continuously fed to the SCIX column. The 2004 work by Wilmarth et al. ${ }^{6}$ investigated loading of RCRA metals (Ag, As, $\mathrm{Ba}, \mathrm{Cd}, \mathrm{Cr}, \mathrm{Hg}, \mathrm{Pb}$, and Se) onto CST. The column run was the same as mentioned in the Pu section (section 3.2) except only the RCRA metals were added to the Tank $41 \mathrm{H}$ dissolved salt cake simulant. ${ }^{7}$ Again, no Cs was added. The total Ba concentration in the simulant was $0.533 \mu \mathrm{g} / \mathrm{mL}(3.89 \mathrm{E}-06 \mathrm{M})$.

A survey of the fraction of total Ba that is Ba-137m in several SRS waste tanks $(13 \mathrm{H}, 30 \mathrm{H}, 37 \mathrm{H}$, $39 \mathrm{H}, 45 \mathrm{~F}, 46 \mathrm{~F}, 49 \mathrm{H},{ }^{10}$ and $41 \mathrm{H}^{7}$ ) indicates it ranges from $1.72 \mathrm{E}-07$ to $1.30 \mathrm{E}-06$. The total Ba concentration converts to $1.42 \mathrm{E}+00 \mathrm{Ci} / \mathrm{gal}(3.74 \mathrm{E}+02 \mu \mathrm{Ci} / \mathrm{mL})$ if the Ba-137m fraction in the total $\mathrm{Ba}$ is assumed to be $1.30 \mathrm{E}-06$, the upper limit of the range. Note that this concentration is about 6.5 times lower than the nominal concentration stipulated in Table 1.

Three thousand BV were also passed through the column followed by washing with $10 \mathrm{BV}$ of inhibited water. Analysis of the washed spent CST gave a Ba loading of $607 \mu \mathrm{g} / \mathrm{g}$. Again, assuming the fraction of total $\mathrm{Ba}$ that is $\mathrm{Ba}-137 \mathrm{~m}$ is $1.30 \mathrm{E}-06$, it converts to a $\mathrm{Ba}-137 \mathrm{~m}$ loading of $4.26 \mathrm{E}-01 \mathrm{Ci} / \mathrm{g}$. For the same reasons as outlined in the Pu section (section 3.2), this loading 
value seems bounding even though the total concentration of Ba used for the test $(0.533 \mu \mathrm{g} / \mathrm{mL})$ is not the bounding value. For example, Tank $13 \mathrm{H}$ has a total Ba concentration of $4.84 \mu \mathrm{g} / \mathrm{mL}^{10}$

In other words, running 3,000 BV of a Cs-free feed solution containing $\mathrm{Ba}$ at $0.533 \mathrm{mg} / \mathrm{L}$ and other RCRA metals would most likely result in a higher Ba loading on CST than, say, 1,000 BV of a Cs-laden feed containing $\mathrm{Ba}$ at $4.84 \mathrm{E} \mu \mathrm{g} / \mathrm{mL}$. This is because the sorbent has the greatest affinity for Cs. Secondly, it is most likely the actual SCIX unit will process or treat less than the 1,000 BV of feed stated here.

Alternatively, using the same data and assuming a linear isotherm results in Ba-137m loadings of $1.20 \mathrm{E}+01$ and $2.77 \mathrm{E}+00 \mathrm{Ci} / \mathrm{g}$ respectively for the maximum and nominal concentrations stipulated in Table 1. The maximum and nominal concentrations of Ba-137m given in Table 1 convert to total Ba concentrations of $1.51+01 \mu \mathrm{g} / \mathrm{mL}(1.10 \mathrm{E}-04 \mathrm{M})$ and $3.46 \mathrm{E}+00 \mu \mathrm{g} / \mathrm{mL}$ (2.53E-05 M) respectively. While the maximum total Ba concentration of $1.51+01 \mu \mathrm{g} / \mathrm{mL}$ seems very high, the nominal total $\mathrm{Ba}$ concentration $(3.46 \mathrm{E}+00 \mu \mathrm{g} / \mathrm{mL})$ is in the ballpark when compared to the Tank $13 \mathrm{H}$ value. It appears for SRS waste tanks, the maximum Ba-137m loading cannot exceed $2.77 \mathrm{Ci} / \mathrm{g}$. It is the utmost upper bound loading, considering the short halflife and length of time for loading.

\subsubsection{Activity from the Decay of the Cs-137 Loaded on the CST to Ba-137m}

The activity of Ba-137m is equal to $94.6 \%$ of the activity of Cs- $137 .{ }^{1}$ Hence, multiply the Cs- 137 loading values (in Table 2) by 0.946 to obtain the corresponding values for Ba-137m. With the short half-life for Ba-137m, the activity for Ba-137m will quickly be defined by equilibrium from cesium decay.

\subsection{Americium (Am-241)}

The loading for the maximum and nominal concentrations of $1.30 \mathrm{E}-02 \mathrm{Ci} / \mathrm{gal}(3.43 \mathrm{E}+00$ $\mu \mathrm{Ci} / \mathrm{mL})$ and 1.20E-03 Ci/gal (3.17E-01 $\mu \mathrm{Ci} / \mathrm{mL})$ given in Table 1 are $1.85 \mathrm{E}-04 \mathrm{Ci} / \mathrm{g}$ and 1.71E$05 \mathrm{Ci} / \mathrm{g}$ respectively. The maximum and nominal loading values are based on a linear isotherm assumption from just one data point because the concentrations are fairly low. Also, the data is from a 6-hour batch contact equilibration test. It is quite possible equilibrium may not have been reached based on the scatter in the data. ${ }^{11}$

\subsection{Strontium (Sr-90)}

A survey of the fraction of total Sr that is Sr-90 in several SRS waste tanks $(13 \mathrm{H}, 30 \mathrm{H}, 37 \mathrm{H}$, $39 \mathrm{H}, 45 \mathrm{~F}, 46 \mathrm{~F}$, and $49 \mathrm{H}$ ) indicates it ranges from $2.64 \mathrm{E}-05$ to $2.85 \mathrm{E}-03 .{ }^{10}$ The concentration stipulated in Table 1 is zero presumably due to pre-SCIX MST strike. However, the highest total Sr concentration found among several SRS waste tanks is $11 \mu \mathrm{g} / \mathrm{mL}(1.26 \mathrm{E}-04 \mathrm{M})$ in Tank $39 \mathrm{H}^{10}$ Based on the ZAM model, ${ }^{12-14}$ this corresponds to a loading of $6.69 \mathrm{E}-03 \mathrm{Ci} / \mathrm{g}$ if the Sr-90 fraction in the total $\mathrm{Sr}$ is assumed to be $2.850 \mathrm{E}-03$, the upper limit of the range.

The total Sr concentration of $11 \mu \mathrm{g} / \mathrm{mL}$ converts to $1.66 \mathrm{E}-02 \mathrm{Ci} / \mathrm{gal}(4.39 \mathrm{E}+00 \mu \mathrm{Ci} / \mathrm{mL})$ if the Sr-90 fraction in the total $\mathrm{Sr}$ is also assumed to be $2.850 \mathrm{E}-03$. 
The ZAM model indicates the uppermost limit of Sr loading on CST is $1.159 \mathrm{mmole} / \mathrm{g}$. Using the same Sr-90 fraction gives a value of 4.05E-02 Ci/g. This uppermost limit value seems to occur at total Sr concentrations of $8.76 \mathrm{E}+04 \mu \mathrm{g} / \mathrm{mL}(1 \mathrm{M})$ and beyond. The Sr-90 concentration using the same fraction is $1.32 \mathrm{E}+02 \mathrm{Ci} / \mathrm{gal}(3.50 \mathrm{E}+04 \mu \mathrm{Ci} / \mathrm{mL})$.

\subsection{Yttrium (Y-90)}

\subsubsection{Y-90 Activity from the Supernate}

The loading value is based on the assumption that the activity of Y-90 in the waste is equal to the activity of Sr-90 in the waste. ${ }^{1}$ From the previous section, the concentration of Sr-90 based on a total Sr concentration of $11 \mu \mathrm{g} / \mathrm{mL}$ equals $4.39 \mu \mathrm{Ci} / \mathrm{mL}$. Using a linear isotherm assumption and a measured $\mathrm{K}_{\mathrm{d}}$ of $32 \mathrm{~mL} / \mathrm{g}$ for $\mathrm{Y},{ }^{15}$ leads to the following equation.

Loading in $\mu \mathrm{g} / \mathrm{g}=32 \times$ (concentration in $\mu \mathrm{g} / \mathrm{mL}$ )

For a Y concentration of 7.98E-06 $\mu \mathrm{g} / \mathrm{mL}(4.39 \mu \mathrm{Ci} / \mathrm{mL})$, the above equation gives a Y loading of $2.55 \mathrm{E}-04 \mu \mathrm{g} / \mathrm{g}(1.40 \mathrm{E}-04 \mathrm{Ci} / \mathrm{g})$. Similarly (as was done in the $\mathrm{Sr}$ section i.e., section 3.5), the uppermost limit of $\mathrm{Y}$ loading is $2.04 \mathrm{E}+00 \mu \mathrm{g} / \mathrm{g}(1.12 \mathrm{E}+00 \mathrm{Ci} / \mathrm{g})$.

Note that the tests from which the $\mathrm{K}_{\mathrm{d}}$ value was obtained used $\mathrm{Y}-88$. The half-life of $\mathrm{Y}-88$ is 106.6 days. Hence, no appreciable decay occurred for the 6-hour equilibration test. In other words, the decrease in solution concentration from the batch contact test was the result of sorption onto CST rather than the decay to Sr-88. Even though the equilibration time seems relatively short, a comparison of the 0.5-hour and 2-hour data with the 6-hour data indicate equilibrium was reached. ${ }^{15}$

\subsubsection{Activity from the Decay of the Sr-90 Loaded on the CST to Y-90}

The activity of Y-90 is equal to the activity of Sr-90. ${ }^{1}$ Hence, use the loading values in the Sr-90 section (section 3.5) similar to the approach for Ba-137m.

\subsection{Uranium}

See the section on $\mathrm{Pu}$ (section 3.2).

\subsection{Curium (Cm-244)}

No data has been found to date.

\subsection{Case 2 of the $2^{\text {nd }}$ Bullet in Objective/Scope Section}

The maximum loadings will be the same as given in Tables 2 and 3 because the discharge waste tank radionuclide concentrations are assumed to be the same as stipulated in Table 1. 
For lower discharge waste tank radionuclide concentrations, desorption can occur in principle. However, tests conducted by Walker in $2000^{16}$ indicate Cs desorption from CST is minimal. The amount desorbed after nine months of storage in $0.2 \mathrm{M} \mathrm{NaOH}$ solution was about $0.03 \%$. No such information is available for the other radionuclides.

\subsection{CONCLUSION}

The loading estimates of all the radionuclides with the exception of Cs-137 (see Table 2) and the $\mathrm{Pu}$ isotopes are summarized in Table 3. The total $\mathrm{Pu}$ loading value is given instead. Data is not available for $\mathrm{Cm}$ and only limited data is available for Am-241. If a bounding number cannot be used from the total tank inventory, then batch contact testing of CST would be recommended.

Table 3. Summary of the Estimates of Radionuclide Loadings on CST.

\begin{tabular}{|c|c|c|c|c|c|c|}
\hline & \multicolumn{3}{|c|}{ Maximum } & \multicolumn{3}{|c|}{ Nominal } \\
\hline Isotope & $\begin{array}{l}\text { Supernate } \\
\text { Conc. }\end{array}$ & $\begin{array}{l}\text { Supernate } \\
\text { Conc. }\end{array}$ & Loading & $\begin{array}{l}\text { Supernate } \\
\text { Conc. }\end{array}$ & $\begin{array}{l}\text { Supernate } \\
\text { Conc. }\end{array}$ & Loading \\
\hline Units & $\mathrm{Ci} / \mathrm{gal}$ & $\mu \mathrm{Ci} / \mathrm{mL}$ & $\mathrm{Ci} / \mathrm{g}$ & $\mathrm{Ci} /$ gal & $\mu \mathrm{Ci} / \mathrm{mL}$ & $\mathrm{Ci} / \mathrm{g}$ \\
\hline Sr-90 & $0.00 \mathrm{E}+00$ & $0.00 \mathrm{E}+00$ & $6.69 \mathrm{E}-03^{\mathrm{a}}$ & $0.00 \mathrm{E}+00$ & $0.00 \mathrm{E}+00$ & See max. loading value \\
\hline Y-90 & $0.00 \mathrm{E}+00$ & $0.00 \mathrm{E}+00$ & $1.40 \mathrm{E}-04^{\mathrm{b}}$ & $0.00 \mathrm{E}+00$ & $0.00 \mathrm{E}+00$ & See max. loading value \\
\hline Y-90 & $\mathrm{n} / \mathrm{a}$ & $\mathrm{n} / \mathrm{a}$ & $6.69 \mathrm{E}-03^{\mathrm{c}}$ & $\mathrm{n} / \mathrm{a}$ & $\mathrm{n} / \mathrm{a}$ & See max. loading value \\
\hline Cs-137 & $4.20 \mathrm{E}+01$ & $1.11 \mathrm{E}+04$ & See Table 2 & $9.80 \mathrm{E}+00$ & $2.59 \mathrm{E}+03$ & See Table 2 \\
\hline Ва-137m & $4.00 \mathrm{E}+01$ & $1.06 \mathrm{E}+04$ & $4.26 \mathrm{E}-01^{\mathrm{d}}$ & $9.20 \mathrm{E}+00$ & $2.43 \mathrm{E}+03$ & See max. loading value \\
\hline Ba-137m & $\mathrm{n} / \mathrm{a}$ & $\mathrm{n} / \mathrm{a}$ & $\begin{array}{c}=94.6 \% \text { of Table } 2 \\
\text { values }^{\mathrm{e}}\end{array}$ & $\mathrm{n} / \mathrm{a}$ & $\mathrm{n} / \mathrm{a}$ & $\begin{array}{c}=94.6 \% \text { of Table } 2 \\
\text { values }^{\mathrm{e}}\end{array}$ \\
\hline $\mathrm{Pu}$ (total) & 2.61E-02 & $6.89 \mathrm{E}+00$ & $\begin{array}{c}5.02 \mathrm{E}-06^{\mathrm{f}} \\
(6.86 \mathrm{E}+01 \mu \mathrm{g} / \mathrm{g}) \\
\end{array}$ & $9.70 \mathrm{E}-03$ & $2.56 \mathrm{E}+00$ & See max. loading value \\
\hline $\mathrm{Pu}-238$ & $1.40 \mathrm{E}-02$ & $3.70 \mathrm{E}+00$ & See total Pu value & 5.70E-03 & $1.51 \mathrm{E}+00$ & See total Pu value \\
\hline $\mathrm{Pu}-239$ & $1.70 \mathrm{E}-03$ & 4.49E-01 & See total Pu value & $4.80 \mathrm{E}-04$ & $1.27 \mathrm{E}-01$ & See total Pu value \\
\hline $\mathrm{Pu}-240$ & $3.80 \mathrm{E}-04$ & $1.00 \mathrm{E}-01$ & See total Pu value & $1.20 \mathrm{E}-04$ & $3.17 \mathrm{E}-02$ & See total Pu value \\
\hline $\mathrm{Pu}-241$ & $1.00 \mathrm{E}-02$ & $2.64 \mathrm{E}+00$ & See total Pu value & 3.40E-03 & 8.98E-01 & See total Pu value \\
\hline Am-241 & 1.30E-02 & $3.43 \mathrm{E}+00$ & 1.85E-04 & $1.20 \mathrm{E}-03$ & 3.17E-01 & $1.71 \mathrm{E}-05$ \\
\hline $\mathrm{Cm}-244$ & $4.00 \mathrm{E}-03$ & $1.06 \mathrm{E}+00$ & No data was found & $1.10 \mathrm{E}-04$ & 2.91E-02 & No data was found \\
\hline $\mathrm{U}^{\mathrm{g}}$ & $\mathrm{n} / \mathrm{a}$ & $\mathrm{n} / \mathrm{a}$ & $3.60 \mathrm{E}+02 \mu \mathrm{g} / \mathrm{g}$ & $\mathrm{n} / \mathrm{a}$ & $\mathrm{n} / \mathrm{a}$ & See max. loading value \\
\hline
\end{tabular}

${ }^{\mathrm{a}}$ Based on Sr-90 supernate concentration of 1.66E-02 Ci/gal $(4.39 \mathrm{E}+00 \mu \mathrm{Ci} / \mathrm{mL})$.

${ }^{\mathrm{b}}$ Based on Y-90 supernate concentration of 1.66E-02 Ci/gal $(4.39 \mathrm{E}+00 \mu \mathrm{Ci} / \mathrm{mL})$.

${ }^{\mathrm{c}}$ Based on Y-90 loaded on CST. Total Y-90 loading $=1.40 \mathrm{E}-04+6.69 \mathrm{E}-03=6.83 \mathrm{E}-03 \mathrm{Ci} / \mathrm{g}$.

${ }^{\mathrm{d}}$ Based on Ba-137m supernate concentration of $1.42 \mathrm{E}+00 \mathrm{Ci} / \mathrm{gal}(3.74 \mathrm{E}+02 \mu \mathrm{Ci} / \mathrm{mL})$.

e Based on Cs-137 loaded on CST.

${ }^{\mathrm{f}}$ Corresponding supernate concentration is unknown.

${ }^{\mathrm{g}} \mathrm{U}$ is not among the isotopes of interest. It is provided as additional information.

n/a - not applicable 


\subsection{REFERENCES}

1. Engineering Document, S-CLC-G-00235, Rev. 3.

2. S. Y. Lee, K. Adu-Wusu and W. D. King, "Task Plan for Thermal Modeling of CST Columns and CST Maximum Loading Determinations,” SRNL-TR-2010-00081, Rev. 0, March, 2010

3. S. E. Aleman and L. L. Hamm, "Small Column Ion Exchange for Removal of Cesium from SRS Low Curie Salt Solution Using Crystalline Silicotitanate (CST) Resin,” WSRC-TR2003-00430, Rev. 0, December 2003.

4. L. L. Hamm, T. Hang, D. J. McCabe and W. D. King, "Preliminary Ion Exchange Modeling for Removal of Cesium from Hanford Waste Using Hydrous Crystalline Silicotitanate Material,” WSRC-TR-2001-00400, July 2002.

5. F. G. Smith, "Modeling of Ion-Exchange for Cesium Removal from Dissolved Saltcake in SRS Tanks 1-3, 37 and 41,” WSRC-STI-2007-00315, Rev. 0, August 2007.

6. W. R. Wilmarth, V. H. Dukes and J. T. Mills, "Reactivity of Crystalline Silicotitanate (CST) and Hazardous Metal/Actinide Loading during Low Curie Salt Use," WSRC-TR-200400588, Rev. 0, November 2004.

7. C. J. Martino, W. R. Wilmarth, D. P. Diprete and C. C. Diprete, "Tank 41H Dissolved Saltcake Sample (HTF-E-03-91 - 92) Saltstone Waste Acceptance Criteria Analysis," WSRC-TR-2003-00380, Rev. 1, September 2003.

8. D. T. Hobbs, "Fissile Solubility and Monosodium Titanate Loading Tests," WSRC-RP-921273, February 1993.

9. D. J. McCabe, L. L. Hamm, S. E. Aleman, D. K. Peeler, C. C. Herman and T. B. Edwards, High Level Waste System Impacts from Small Column Ion Exchange Implementation,” WSRC-TR-2005-00034, Rev. 0, August 2005.

10. M. E. Stallings, M. J. Barnes, T. B. Peters, D. P. Diprete, F. F. Fondeur, D. T. Hobbs and S. D. Fink, "Characterization of Supernate Samples from High Level Waste Tanks 13H, 30H, 37H, 39H, 45F, 46F and 49H,” WSRC-TR-2004-00386 Rev. 2, June 2005.

11. S. F. Marsh, Z. V. Svitra and S. M. Bowen, "Distributions of 14 Elements on 63 Absorbers from Three Simulant Solutions (Acid-Dissolved Sludge, Acidified Supernate and Alkaline Supernate) for Hartford HLW Tank 102-SY,” Los Alamos National Laboratory, LA-12654, Rev., August 1994.

12. Z. Zheng, R. G. Anthony and J. E. Miller, "Modeling Multicomponent Ion Exchange Equilibrium Utilizing Hydrous Crystalline Silicotitanates by a Multiple Interactive Ion Exchange Site Model,” Ind. Eng. Chem. Res., 36, 2427-2434, 1997. 
13. Z. Zheng, C. V. Phillip, R. G. Anthony, J. L. Krumhansl, D. E. Trudell and J. E. Miller, "Ion Exchange of Group I Metals by Hydrous Crystalline Silicotitanates,” Ind. Eng. Chem.Res., 35, 4246-4256, 1996.

14. Z. Zheng, D. Gu and R. G. Anthony, 1996. "Estimation of Cesium Ion Exchange Distribution Coefficients for Concentrated Electrolytic Solutions When Using Crystalline Silicotitanates,” Ind. Eng. Chem. Res., 34, 2142-2147, 1995.

15. Z. V. Svitra, S. F. Marsh and S. M. Bowen, "Distributions of 12 Elements on 64 Absorbers from Simulated Hartford Neutralized Current Acid Waste (NCAW),” Los Alamos National Laboratory, LA-12889, Rev., December 1994.

16. D. D. Walker, “Cesium Sorption/Desorption Experiments with IONSIV ${ }^{\circledR}$ IE-911 in Radioactive Waste,” WSRC-TR-2000-00362, Rev. 0, December 2000. 